\title{
An Analytical Study on the Philosophical Concepts of Vaiśeșika Included in the Āyurvedic Treatments (Based on Carakasamhitā, Susruta samhitā, and Vaiśeșikasūtra)
}

\author{
Rev. Kumburuwela Seelananda
}

${ }^{1}$ University of Peradeniya

\section{Email:Seelanandakumburuwela@yahoo.com}

\begin{abstract}
Both Āyurweda and Philosophy are two subject streams, which are more close to the worldly and spiritual lives of human beings. Their connection is non-separable even in the beginning of these two systems. Therefore, it is worthy to investigate the connection between these two systems according to the cognition of seven categories and atoms, which are defined in the philosophy of Vaiśeșika and how they are applied for the treatments of Āyurveda. The enumeration of categories included in Vaiśeșika system such as; Dravya, Guṇa, Karma, Sāmānya, Viśeșa, and Samavāya have been applied for the descriptions in the Āyurvedic treatments. Both these systems accept that the substance is the main component and that others all depend under the substance. Vaiśeșika mentions of five types of Karma developed by Ūrdhva etc. Caraka and Susṛta have discussed about Pañca karma, Agni karma, Jāta karma etc. According to the philosophy of Vaiśeșika, Sāmānya (General) means similarity of all objects and each other. For instance, the existence in combinative position of Substance, Attribute, and Action are depended upon their appearance of Sāmānya as well as Viśeșa. In Āyurvedic system, one of the fundamental elements is awareness of resemblance. The resemblance of the substance, attribute, and action is always becomes the cause of increasing healthiness. On the other hand, their dissimilarity is the cause of reducing healthiness itself. Both systems accept that the Ātma is eternal. From these facts, it would appear that the Āyurvedic system have applied the concepts in philosophy of Vaiśeșika for the use of a practical methodological system.
\end{abstract}

Keywords: saptapadārtha, substance, atoms, ātma, vaiśeșika

\section{INTRODUCTION}

Āyurveda is a science of treatment of deseases, which cause physical, and mental illnesses. The connection between philosophy and Āyurveda is non-separable and it has been prevalent since the beginning of these two sciences in the past. For instance, some philosophical concepts contained in the six philosophies in India were absorbed for some explanations of the medical treatments in Āyurveda. The present study will focus on the seven categories and atomism, which are the teachings of vaiśeșika established by Kanāda. The objective of the research is to investigate the worthiness of the seven categories and atoms for the treatments of Āyurveda. Though Suśruta did not accept the attribute of Paratva, he applied Guru, and Laghu for his explanation of the treatments of medicine.

\section{Methodology}

The present research is mainly based on primary data. The texts, which mentions about philosophy and Āyurvedic texts in Sanskrit will be subjected to thorough research to arrive at conclusions along with the secondary sources. In order to understand the worthiness of the seven categories (sapta padārtha) and atoms of philosophy for Āyurvedic treatments, the comparative and analytical method would be used.

\section{Literature Review}


Following are some of the important works related to the subject matter of the present study. The Vaiśeșikasūtra of Kaṇāda, edited by Major B.D.Basu is a worthy treatise in relation to the subject for the versatility of seven categories. In fact, Vaiśeșikasūtra, the prime treatise for Vaiśeșikasūtra philosophy, mentioned only six categories. The seventh one (Abhāvapadārtha) was included by the philosophers belonging to post Vaiśeșika such as Śrīdhara, Udayana, Śivāditya etc. Padhārthadharmasamingraha written by Praśastapāda is another treatise relating to the present study. There are four commentaries written on the work of Praśastapāda, which are named as Vyomavatī of Vyomaśekhara, Nyāya Kandalī Śīdhara, Kiran̄āvalī of Udayana, and Līlāvatī of Śrī Vatsa. In considering the Āyurvedic literature relating to the study, Caraka and Suśrta Saṃhitās are the main treatises. The study also utilizes Carakasaṃhitā by Agniveśa, edited by Vaidya Jadavaji Trikamji Ācārya and the Suśṛta Saṃhitā of Suśṛta, edited by Vaidya Jadavaji Trikamji Ācārya.

\section{Discussion}

\section{The system of Āyurveda}

Āyurveda is a science of medicine in the world with its historical roots in the Indian subcontinent. It is a system of preventing physical and mental diseases. The name Āyurveda is derived from the sound 'Âyush' and the verb root of 'Vid' indicating the meaning knowledge of life. For instance, this is designated as Āyurveda where advantages and disadvantages as well as happy and unhappy life along with what is good and bad for life, its measurement and life itself are described. Suśrta defines on the term of Āyurveda as; the life existing here or a one who acquires life. It acquires four objects of the human existence (Purușārtha) named virtue (Dharma), wealth (Artha), desires (Kāma), and salvation (Mokśa).

According to Caraka, Āyurveda is introduced by Brahma. In addition, both Caraka and Suśrita Saṃhitās mention that it is a branch of Atharvaveda. However, it is apparent that Āyurveda has a long historical background in India because some scholars attempt to categorize it into three parts as the periods of pre-Vedic, Vedic, and post-Vedic. Pre-Vedic medicine was used since Indus Valley Civilization to the Vedic period. Vedic medicine include in the period of Vedic literature. The knowledge of the medicine of Vedas is derived from two Vedas, the Rgveda and the Atharva-veda. The post-Vedic Medicine can be divided into two sub-periods; the first existed from the completion of the collection of the Vedic hymns (800 B.C.) to the rise of medical schools (600 B.C.), the second existed from the rise of the medical schools to the end of classical Indian medicine.

The schools of Ātreya and Dhanvantarī can be considered to have been established in the sixth century B.C. In fact, Caraka and Suśṛta saṃhitās, which are precious treatises of Ātreya and Dhanvantarī, include in the period of 600 B.C. - 200 A.D. Another valued work related to the present study is Aśțāngahṛdayasamihitā written by Vāgbhața. These Caraka, Suśṛta, and Aśțāngahṛdaya samhitās are called Vrrddhatrayī (the great three treatises) in Āyurvedic literature. In spite of these three main works, Mādhavanidāna, Śāraṅgadharasamihitā, and Bhāvaprakāśa are called Laghutraȳ̄ (small three treatises). Besides these books, there are several other works in the Âyurvedic literature.

The period of post-Vedic medicine can be considered as an especial one because the Brāhmaṇa, Upanișad, Jain and Buddhist philosophical and religious influences can be clearly seen in this period. From the six systems of Indian philosophy, the Sānkhya, Yoga, Mīmānsa, and Vaiśeșika were prior to Buddhism. Therefore, it can be considered that the philosophical concepts of Vaiśeșika have probably influenced the Āyurvedic literature.

\section{The system of Vaiśeșika philosophy}

The foundations of the Vaiśeșika philosophical system can be ascribed to the second century B.C. According to traditional belief, the originator of Vaiśeșika philosophy is Kanāda. He lived in 150 $200 \mathrm{CE}$. His most famous treatise related to this philosophy is Vaiśeșikasūtra. According to the rule of Pāninīi (IV.iii.87), this word is derived from 'Viśeșa' meaning 'a treatise on Viśeșa'. It is clear that the scholars of India also believed this name has derived because the name 'Viśeșa' is included in one of the seven categories. The seven categories are 1.Dravya (substance), 2.Guna (quality), 3.Karma (action), 4.Sāmānya (generality), 5.Viśeșa (particularity), 6.Samavāya (relation of inherence), and Abhāva (nonexistence). 
The categorization of seven Padārthas and their sub-categories can be illustrated from the following chart.

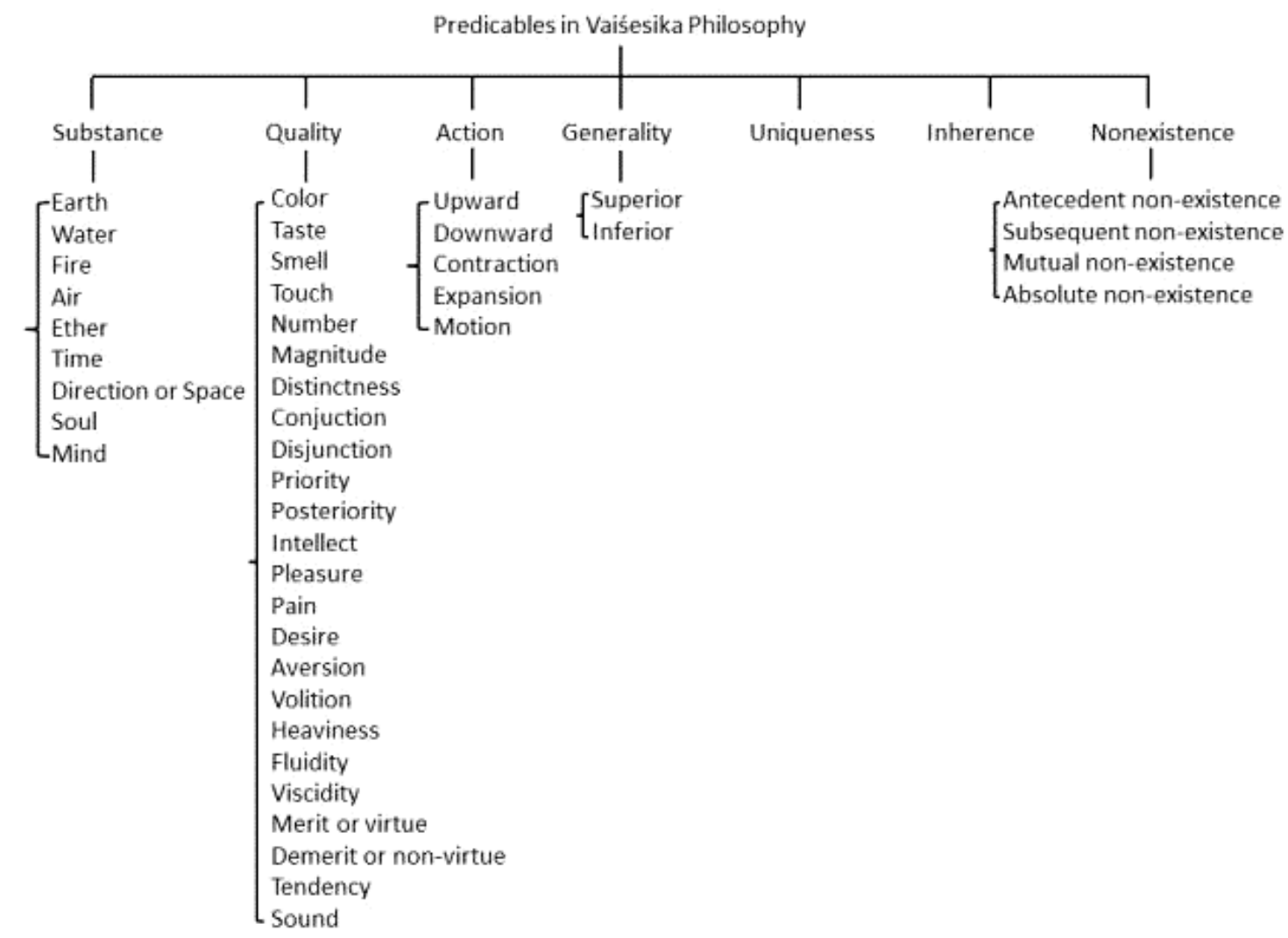

\section{The relationship between Vaiśeșika system and Āyurvedic system}

Âyurveda enumerates on the components such as world, the genesis of the human, the constituents of the human and universe following the philosophical thoughts of Nyāya-Vaiśesika, Sānkhhya-Yoga, and Mīmānsa and Upanișad. Though the main purpose of philosophy is to recognize how to gain eternal salvation, the purpose of Âyurveda is to prevent diseases, preserving the good health, and getting four objects of desire ((Purușārtha). The main objective of the present study is to investigate the connection between Āyurveda and philosophical thoughts introduced in the philosophy of Vaiśeșika. The enumeration of categories included in the Vaiśeșika system such as; Dravya, Guṇa, Karma, Sāmānya, Viśeșa, and Samavāya have been applied in the descriptions of Āyurvedic treatments. The components of similarity relating to the categories of these systems are shown in the following table.

\begin{tabular}{|c|c|c|}
\hline Categories & Vaiśeșika system & Āyurvedic system \\
\hline Dravya & $\begin{array}{llll}\text { Prtthivi, } & \bar{A} p a s, & \text { Tejas, } & \text { Vāyu, } \\
\text { Ākāśa, } & \text { Kāla, } & \text { Diśāa } & \overline{\text { Ātma, }} \\
\text { Manas. } & & & \end{array}$ & $\begin{array}{l}\text { Ākāśa, Vāyu, Agni, Jala, Kșiti } \\
\text { (Pañcabhūta), Ātma, Manas, } \\
\text { Kāla, Diśáa.. }\end{array}$ \\
\hline Guṇa & $\begin{array}{lr}\text { Rūpa, Rasa, } & \text { Gandha, } \\
\text { Spharśa,Sañkhyā, } & \text { Parimāṇa, } \\
\text { Pṛthaktva, Sañyoga, Vibhāga, } \\
\text { Paratva, Aparatva, Gurutva, } \\
\text { Dravatva, Sneha, Śābda, Buddhi, } \\
\text { Sukha, Dukkha, Iccā, Dveśa, }\end{array}$ & $\begin{array}{l}\text { Śabda, Sparśa, Rūpa, Rasa, } \\
\text { Gandha, Guru, Laghu, Śīta, } \\
\text { Uș̣na, Snigdha, Rūkśa, Manda, } \\
\text { Tịkșna, Sthira, Sara, Mṛdu, } \\
\text { Kațina, Viśada, Picchila, Khara, } \\
\text { Ślakșnna, Sthūla, Sūkșma, Sāndra, }\end{array}$ \\
\hline
\end{tabular}

${ }^{1}$ p\&iwVyapStejae vayurakaz< kalae idgaTma mn \#it ÔVyai[, - Vaiśeșika Sūtra1.1.5

The Valśeșika Sūtras of Kaṇāda, vol. Vi, ed. Nandalal Sinha (Allahabad: Vijaya press, 1923), 17.

2 oadINyaTma mn $>$ kalae idzí ÔVys $<\phi \mathrm{h}>$,

seiNÔy $<\operatorname{cetn}<\hat{O} V y<$ iniriNÔymcetnm!. 48. - Carakasamhitā - I.1.48 


\begin{tabular}{|c|c|c|}
\hline & $\begin{array}{l}\text { Prayatna, Dharma, Adharma, } \\
\text { Sanskāra. }{ }^{3}\end{array}$ & $\begin{array}{l}\text { Drava, Smṛti, Cetanā, Dhrti, } \\
\text { Ahañkāra, Buddhi, Iccā, Dveșa, } \\
\text { Sukha, Dukkha, Prayatna, } \\
\text { Paratva, Aparatva, Yukti, } \\
\text { Sañkhyā, Sam̄yoga, Vibhāga, } \\
\text { Pṛthaktva, Parimāṇa, Sanskāra, } \\
\text { Abhyāsa. }\end{array}$ \\
\hline Karma & $\begin{array}{l}\text { Utkșepaṇa, Avakșepaṇa, } \\
\text { Ākuñcana, Prasāraṇa, Gamana. }\end{array}$ & $\begin{array}{l}\text { If something is feasible with } \\
\text { endeavor or effort is caused to } \\
\text { something, it is called Karma } \\
\text { (action). }{ }^{6}\end{array}$ \\
\hline Sāmānya & $\begin{array}{l}\text { Substance is general (Sāmānya) } \\
\text { cause of dravya, Guṇa, Karma. }\end{array}$ & $\begin{array}{l}\text { General of all objects is caused } \\
\text { for the preventing healthiness. }{ }^{8}\end{array}$ \\
\hline Samavāya & $\begin{array}{l}\text { The resemblance of Substance } \\
\text { and Attribute is the characteristic } \\
\text { of being the originators of their } \\
\text { congeners. }{ }^{9}\end{array}$ & $\begin{array}{l}\text { If there is some non-separate } \\
\text { existence of substances such as } \\
\text { earth etc. with their qualities, it is } \\
\text { called Samavāya (inherence). }{ }^{10}\end{array}$ \\
\hline
\end{tabular}

As mentioned above, the analytical explanation on the connection between Vaiśeșika and Āyuvedic systems can be elaborated from here onwards as follows. According to Vaiśeșikasūtra, from seven categories, the substance is the main component and others depend under the substance. The Āyurvedic system also accept that idea because Caraka points out that the substances are the main components for treatments of medicine.

It is obvious that the nine Substances which were mentioned by Kaṇāda and Caraka are similar; however, the sequence of mentioning the terms is quite different. According to the Vaiśeșika system, the attributes are twenty four (24). In Āyurvedic system, though Caraka included those 24 attributes for his elaboration of the treatments, Suśruta did not accept the attribute of Paratva. He applied Guru, and Laghu for his explanation of the treatments of medicine. However, Vaiśeșika mentions five Karma as Ürdhva etc., Caraka and Susṛta, which includes Pañca karma, Agni karma, Jāta karma etc. Considering these facts, it would appear that the Āyurvedic system have applied the philosophical concepts of Vaiśeșika for its practical methodological system.

According to Vaiśeșika philosophy, Sāmānya (General) means similarity of all objects with each other. For instance, the existence in combinative position of Substance, Attribute, and Action are depended upon their appearance of Sāmānya as well as Viśeșa. In Āyurvedic system, one of the fundamental elements is awareness of resemblance. The resemblance of the substance, attribute, and action is always the cause of increasing healthiness. On the other hand, their dissimilarity is the cause of reducing healthiness itself. For instance, the acidity of Āmalaka (Indian gooseberry) causes to reduce the acidity of bile in the body because of its quality of frigid Āmalaka. It is an instance for pointing out the way to get resemblance of Substances. If the resemblance of Substances is not preserved, it is the cause for the increase of diseases because of the dissimilarity of Substances. Therefore, it is apparent that the consept of Sāmānya and Viśeșa in the philosophy of Vaiśeșika have been applied for the enumerations of the treatments in Āyurveda.

The preserving of Substances depend on three forms-body, sense, and objects. In Āyurvedic system, there is a concept named similarity with universe and individual (loka puruṣa sāmya). It is a kind of a similarity with nature and human beings. It is accepted in Āyurveda that there is a combination between nature and man in the perspective of acting substances, attributes, and action. Mind (Sattva), Soul (Ātma), Body (Śarīra) are three sticks. The world or life is being with the help of these three elements. Therefore, the beings get affected by different matters in the out word world. This life can be named as Purusa and it is a cause of Āyurveda. Āyurveda has been uttered for the sake of this cause.

\footnotetext{
${ }^{3}$ êprsgNxSpzaR $>\mathrm{s}<$ Oya $>$ pirma[ain $\mathrm{p} \& \mathrm{w}{ }^{\circledR \mathrm{V}}<\mathrm{s}<$ yaeg ivyaeg prTvprTve bul̈y $>$ suoÊ $>$ oe \#1/2aÖe; aE àynaí gu[a $>$ Vaiśesika Sūtra1.1.6 
From this fact, it is clear that some fundamental elements such as soul, mind, body etc. have been applied from the philosophy of Vaiśeșika for the treatments in Āyurveda.

The concept of atomism was firstly introduced by Kanāda in his Vaiśeșikasūtra. According to him, the primary atoms are eternal. Activated or created atoms are impermanent. In Āyurvedic system, all worldly aspects can be divided into two parts as Cetana and Acetana. Created one is non-eternal. When the body is concerned, Vāta (Air), Pitta (Pile), Kapha (Phlegm), Sapta Dhātu (Seven components), and Trimala (Three kinds of unclearness) are impermanent. Ātmā is eternal. His enumeration of the atoms can be seen as the types of once, second, third, and forth. The power of activeness of the atoms has basically connected with two atoms and their manipulator is god İsvara. Nevertheless, Caraka mentions that the power of activeness of the atoms belongs to itself. In this manner, two systems accept that the Ātma is eternal.

\section{CONCLUSION}

Taking the above mentioned facts into consideration, the most obvious finding which emerge from the present study, can be mentioned as follows. It is obvious that, Āyurvedic system was developed with the help of Indian philosophical systems. Out of those, one of the most precious philosophies is Vaiśeșika. Therefore, it is perspicuous that the philosophical concepts of Vaiśeșika such as seven categories, atoms etc. have influenced the enumeration of treatments in the Âyurvedic medical system.

\section{REFERENCES}

1. Carakasamhitā by Agniveśa. ed. Vaidya Jadavaji Trikamji Āchārya. Bombay: Nirṇaya Sāgar Press, 1941.

2.

3. Keith, A. Berriedale, A History of Sanskrit Literature. London: oxford clarendon press, 1928.

4. Kutumbiah, P. Ancient Indian Medicine. Bomby: Orient Longman, 1962.

5. Suśrutasaṃhitā of Suśruta. ed. Nārāyaṇ Rām Āchārya. Bombay: Nirṇaya Sāgar Press, 1945.

6. Tarka Samgraha of Annambhaț̣a. ed. Mahadev Rajaram Bodas. Poona: Bhandarkar Oriental Research institute, 1930.

7. The Vaiśeșika Sūtras of Kaṇāda. vol. Vi, ed. Nandalal Sinha. Allahabad: Vijaya press, 1923. 